\title{
Journal of Economics, Race, and Policy
}

\section{William Darity $\mathrm{Jr}^{1}$}

Published online: 18 June 2018

(C) Springer International Publishing AG, part of Springer Nature 2018

The Journal of Economics, Race, and Policy (JERP) is an important and welcome addition to the canon of professional journals in the economics profession. A thick interconnectedness between race, public policy, and economic well-being has characterized American society since the founding of the Republic. The USA was formed with the appropriation of the lands of indigenous peoples, the continued enslavement of African peoples, and the creation of whiteness as a category applied progressively to all European immigrants. Racialization processes supported by state policy span the globe - whether embodied in caste hierarchy in India, genocidal violence in Bosnia in 1995 or the Turkish genocide directed against the Armenians in 1915, colorism in Brazil, or the Stolen Generations in Australia. Policies including affirmative action, reparations, and group-specific income or wealth redistribution measures have been introduced to counter patterns of state action that have created and maintained racialized inequalities. Given the scope and magnitude of the issues produced by race and racism from a cross-national perspective, the introduction of JERP provides a fresh outlet for systematic research on these core social problems. For many years, the only journal devoted singularly to studies of the economics of race has been the National Economics Association's Review of Black Political Economy. Now the expanding and rich field of race studies with a focus on economics and policy has a new and dynamic journal, the Journal of Economics, Race, and Policy, that only can enhance the growth and development of this critical field of inquiry.

William Darity, Jr

william.darity@duke.edu

1 Duke University, Durham, North Carolina, USA 